\title{
An Ethnographic and Humanistic View: Does the BC Human Rights Tribunal Hold Promise for Indigenous People?
}

\author{
Bruce Granville Miller \\ 'University of British Columbia, Department of Anthropology, Canada
}

\begin{abstract}
In this paper I consider if the $\mathrm{BC}$ human rights tribunal holds promise for Indigenous peoples or is best understood as Trojan horses that absorb the energies of people who have experienced discrimination and as state-centered institutions which are unable to engage with Indigenous values and practices. The data are derived from an examination of all decisions given by the British Columbia Human Rights Tribunal to sort out those brought by or against Indigenous people, interviews with tribunal members and human rights lawyers with tribunal experience, an examination of a seminal case, Radek, and published studies of Indigenous awareness of and attitude towards tribunals. I argue that the tribunal process fails Aboriginal peoples on several grounds and very few cases result in final decisions. But, significantly, the tribunal allows for transformational cases that substantively change the circumstances for Indigenous people of the province.
\end{abstract}

Key words: Indigenous, law, human rights, ethnography. 


\section{Uma Perspectiva Etnográfica e Humanística: O Tribunal de Direitos Humanos da Columbia Britância oferece uma esperança para os Povos Indígenas?}

\section{Resumo}

Neste artigo pergunto se o Tribunal de Direitos Humanos da Colúmbia Britânca oferece uma esperança para os povos indígenas ou se é melhor compreendido como um cavalo de Tróia que absorve as energias de pessoas que experimentaram discriminação, e como instituições centradas no estado que são incapazes de engajar com os valores e as práticas indígenas. Os dados resultam de um estudo sobre todas as decisões proferidas pelo Tribunal de Direitos Humanos da Colúmbia Britânica para separar aquelas impetradas por ou contra povos indígenas, entrevistas com membros do tribunal e advogados de direitos humanos com experiência em tribunais, um estudo de um caso seminal, Radek, e estudos publicados sobre a consciência indígena e sua atitude em relação aos tribunais. Argumento que o processo do tribunal falha com os povos aborígenes por vários motivos e muito poucos casos resultam em decisões finais. Mas, significativamente, o tribunal permite casos transformacionais que mudam substancialmente as circunstâncias para os povos indígenas da província.

Palavras-chave: indígena, lei, direitos humanos, etnografia. 


\title{
An Ethnographic and Humanistic View: Does the BC Human Rights Tribunal Hold Promise for Indigenous People?
}

\author{
Bruce Granville Miller
}

My work as a professor of anthropology at the University of British Columbia, Vancouver, Canada has taken me into human rights tribunals on a number of occasions and in various sorts of ways. In some instances, it has been to give expert testimony about the circumstances surrounding the lives of Indigenous peoples who have experienced some sort of social wrong. In others, it has been as an observer of human rights processes. These observations have taken place in the tribunal rooms themselves as hearings were underway. But the observations have also been of participants engaged in activities of the tribunal in coffee shops and restaurants, law offices, and in conversations in recess rooms in the tribunal offices. Over time, I've talked with tribunal members, human rights lawyers, and litigants. I also observe myself undertaking activities related to the human rights tribunal, in talking with those who have brought cases, in carrying out archival research related to cases, in taking notes, and in writing reports to the tribunal.

In addition, in my role as a classroom teacher, I have directed successive classes of undergraduate students in their studies of the British Columbia Human Rights Tribunal (BCHRT) decisions regarding a great array of topics. These students have wondered; how does the tribunal work for Metis people, or for gay and lesbian litigants? Does the size of awards assigned to winning cases favor certain categories of cases? They ask, as new categories of those who may bring cases are created, is the tribunal more likely to find in the favor of members of these categories? What are the discernable trends? The students have uncovered surprising features of the tribunal but they have been limited to examining decisions. Most have not been on site to observe the tribunal in action and, as is my case also, have not observed tribunal staff at work answering inquiries from the public about whether and how they might bring an action. Curiously, it became clear to me over several years that the students were disturbed by the tribunal, and although they had almost uniformly been advocates of human rights, and presumably of tribunals, had come to view the tribunal negatively. I've come to understand features of the tribunal, as it actually operates, and not as it exists on paper, which worry me and has led me to believe that tribunals are more limited in their effectiveness than one might hope.

Primarily using data from and about the BC Human Rights Tribunal I found that the tribunal process fails Indigenous peoples on several grounds; it is too distant from their experience, requires too much legal assistance, places them in disadvantaged positions and power imbalances relative to others, among other issues. The tribunal experience creates fear and is traumatic in many cases. Very few cases result in final decisions. But, significantly, the tribunal allows for transformational cases that substantively and positively change the circumstances for Aboriginal people of the province. I draw on the Radek case. Other cases are mediated successfully in favor of the Indigenous complainant.

My purpose here is not to undertake a formal analysis of decisions rendered by a human rights tribunal, although I have done that, but rather to look at the human experience of the tribunal experience holistically. I am not attempting a legal analysis of a tribunal but rather an anthropological understanding of how a tribunal is experienced by those people engaged in its processes. In doing this, I am making myself the primary 
instrument of understanding in creating a humanistic ethnography, and within the context of the anthropology of courtrooms and the importance of witnessing within the legal system (for example, Eltringham 2012). Wilson (2006: 77) writes, "An ethnographic approach to human rights is especially appropriate because the human rights regime includes a vast array of different kinds of moral and political projects, which are often incompatible." This paper falls generally into the domain of the anthropology of law and more specifically the subfield of the ethnography and law, an expansive field of inquiry (Goodale 2017 is a recent overview of the anthropology of law; Starr and Goodale, 2002 and Darien-Smith, 2007 overviews of ethnography of law; other more regional studies include Dara Culhane, 1998, and Daniel T. Boxberger, 2004, pp. 323-28). To be more specific, in this paper my concern is primarily with the British Columbia Human Rights Tribunal. Because my own work over the last forty years has concerned Indigenous issues, many of them legal, my interest is in Indigenous cases and litigants who have brought their concerns to the tribunal.

\section{Methods}

There are features of legal processes that are best understood from the inside, as an actor in the formal and informal proceedings. For this reason, some of my data comes from cases in which I have been retained as an expert and have submitted an expert report and/or testified in the tribunal. The first of these cases, Radek $v$ Henderson, concerned a First Nations woman who was mistreated by security guards in a large mall in downtown Vancouver. (Note: Gladys Radek is a public figure so I have not obscured her name, as I have in another case). This case was heard in the BCHRT and has turned out to be significant and I give attention to how the case was engaged and what the downstream impacts have been. A second case in which I was retained was never heard after I submitted my expert report with the BCHRT, but provides an insight into tribunal processes. This case arose after an inter-tribal group attempted to create a small treatment centre for youth at risk and was opposed by townsfolk who placed egregious ads in newspapers and signs on streets associating Indigenous youth and violence. In this instance, confronted with my report, the respondent simply gave up and agreed to remove the signs and to submit no more ads.

A third case is an outlier as it was with the Yukon Human Rights Tribunal, and in which I gave testimony, including cross examination, by telephone. This one was about discrimination in hiring practices. The particular feature to this case was that the tribunal found in favor of my opinion that discrimination against an Indigenous man had occurred but that did not affect the decision to give him no remediation. The lawyer found this puzzling and I do, too, and I wonder what the client made of this. Surely, he felt his time and effort had been wasted.

A fourth case involves charges of rough police misbehavior towards an Indigenous woman living in Vancouver. In this case, too, I was commissioned to write an expert report about the incident and how it may have affected an Indigenous person. In each case, something new was revealed about the tribunal and how it operates and how individuals experience it. In writing about these cases, I rely on my own fieldnotes, recorded during the hearings, documents from each case, my reports filed with the tribunals, and my conversations and other experiences with those bringing the cases.

In addition to these cases experienced as an expert, I also rely on cases I have attended as a witness. The most significant of these in my reading of the tribunal is $\mathrm{McCue} v \mathrm{UBC}$, heard in 2016. In this instance, I attended the three weeks of hearings, and read the decisions, both preliminary and final. But I also spent time with June McCue in an effort to help her carry the several large suitcases of documents she brought from her home to the tribunal and hauled back each evening. We talked at the breaks and on the rides back as she dropped me off at my home. I had no formal part in this case, although I sometimes provided my opinions about what the 
counsel for UBC was attempting and how the hearing was going. I had informal conversations with colleagues at UBC about the implications of the case. I do not seek to offer an opinion about the merits of her case and the decision but the case as heard, and Ms. McCue's comments about it, gave me a powerful glimpse into the efficacy of the tribunal and its human costs. This hearing, for all its legal trappings, registered on the human scale as profoundly disturbing, and I will describe why later on.

My approach to the BC HRT also builds on other sources, of course. I took the time to read all of the decisions involving Indigenous peoples in the BC HRT in the period from 1997 to 2015 and sorted them by outcomes so that I could get a quantitative sense of the tribunal. I consider some of these results below. I have talked with various personnel involved with the tribunal and I discuss their insights. And, I consider the pertinent literature about tribunals and this one in particular. I take particular note of a recent study commission by the BC Human Rights Tribunal about Indigenous people's experiences with the tribunal (Walkem, 2020). This report, written by an Indigenous lawyer, leaves out the part I want to emphasize here, namely the experience of the hearings themselves. The Walkem report relies on survey data and a legal perspective. Most significantly, Walkem pointed to the problem of the tribunal as a gatekeeper and the resulting difficulties in accessing the tribunal, the limited awareness of Indigenous people of the tribunal, problems in language (and the need for plain language in the website and processes), problems in obtaining legal representation, and the lack of Indigenous perspectives and personnel in the tribunal, among other issues. I have found all of these to be serious obstacles for the participation of Indigenous peoples. But first, the structure on which these issues are appended.

\section{Background}

The British Columbia, Canada, Human Rights Tribunal

Human Rights Tribunals are a recent development in the Canadian legal system, following from the logic of the 1948 Universal Declaration of Human Rights promulgated in the post-war United Nations. The human rights concept seems to hold considerable promise for individuals, groups of individuals, and possibly "peoples" burdened by discrimination. The B.C. Human Rights Tribunal (BCHRT) is an independent, quasi-judicial body created by the B.C. Human Rights Code. The Tribunal is responsible for screening, accepting, mediating, and adjudicating human rights complaints. The Tribunal offers the parties to a complaint the opportunity to try to resolve the complaint through mediation. Respondents have an opportunity to respond to a complaint and to apply to dismiss a complaint without a hearing. If the parties do not resolve a complaint and the complaint is not dismissed, the Tribunal holds a hearing. Under the code, cases of discrimination can be brought under the following categories: discrimination in publication, accommodation, service or facility, purchase of property, tenancy, employment advertisements, wages, employment, unions and associations. In each case, the discrimination may be based in the race, colour, ancestry, place of origin, religion, marital status, family status, physical or mental disability, sex, sexual orientation or age of that person or that group or class of persons (http:/|www.bchrt.bc.ca/, accessed April 16, 2020). 
It remains unclear if human rights tribunals are created in a way that allows them to meet the goals they espouse. The notion of human rights itself has been the subject of criticism as existing solely within a western, Eurocentric frame of reference. Human rights commissions and tribunals have been said to be unable to remedy problems facing non-western communities, especially those organized collectively or whose members hold views of the world outside of the highly individualistic and materialistic premises of modernity. Because human rights are framed within the system of states, members of societies which are not included among the states admitted to the United Nations are thought to be inherently disadvantaged. This includes the indigenous peoples of North America and elsewhere. Mullings (2009: i), for example, puts it bluntly, "some [visible minorities] who have filed a claim [in the Canadian Human Rights Tribunal] feel that the institutions that were created to protect them have instead perpetuated discrimination." She argues that racism is reproduced at the tribunal level (ibid.) and "the perspective of the Tribunal adjudicators, which deeply influences how they hear and respond to complaint cases, allows them to ignore everyday racism in the workplace, normalize racist action and policies, and blame the complainants for their experiences. I conclude that until the way in which these cases are heard changes, including the standard for accepting evidence, visible minorities will continue to be re-victimized" (2009: ii). The Walkem report confirms these findings regarding the BCHRT.

Further, the Native Women's Association of Canada pointed to problems of tribunals: "Legal systems and dispute resolution processes that presume their own neutrality despite the exclusion and silencing of indigenous values and perspectives constitute a continuation of the colonization process (Native Women's Association of Canada 2011: 73).

Simultaneously human rights tribunals seem to be both largely invisible and irrelevant to the public at large and the object of occasional scorn for their apparently outlandish rulings in favour of people perceived as undeserving complainants. Newspapers regularly feature columns about the purported absurdity of litigation, the lack of common sense of the tribunal, the reliance on political correctness, and the triviality of cases brought.

Yet from another perspective, human rights and Indigenous rights are indivisible and are essential in a world still built on racist values and practices and colonial frameworks. Green and colleagues (2014), in fact, argue that the path from colonialism to reconciliation goes through Indigenous human rights. Peetush (2009:190) takes note of the contradictory nature of human rights discourse as it relates to Indigenous peoples worldwide. He observes that the discourse helps Indigenous people articulate claims for cultural recognition in the struggle for self-rule. My work with Indigenous people who have brought cases certainly confirms this perspective. However, Peetush notes that human rights bring along with them "powerful theoretical underpinnings, assumptions, and institutions that are at odds with and that undermine what most Native communities in Canada take to be an essential component of their cultural identities and self-understandings" (ibid.). He describes human rights concepts as "biased towards Western liberal ideals," which are not universal, even when they are described as such. Further, the dialogue must be recast within Indigenous perspectives for it to be fruitful (ibid.).

Peetush describes imperialism as acting most forcefully in the "colonization of the realm of ideas or consciousness as opposed to physical space. It consists in the uncritical and illegitimate universalization of a narrow and specific perspective of human experience to all of humankind (Ibid.: 192). Diversity, he writes, lacks legitimacy. The struggle for self-rule, an important part of decolonization, is a struggle for differences. The "Native challenge to human rights involves just this: It is about having the power to articulate, balance, and specify cross-cultural and universal human values within the structures of native self-understandings 
"(Ibid: 193). I disagree with Peetush to the extent that he understates the use of spatial segregation in the construction of colonial regimes, yet he touches on an important perspective (see Mawani 2009 concerning the use of segregation of Indigenous people in Canada).

Part of this problem is that the individual rights discourse is built on human rights so that, to Peetush, rights can act as a "social, political, and economic Western Trojan horse..." (Ibid.: 194). The state acts as a referee between individuals with differing interests and neutral regarding questions of religion and morality. But aside from limited purposes, such as policing, fixing roads, and so on, the state relies on individual action. This, one can suppose, opposes the collectivist orientation said to underpin Aboriginal life (see Christie, 2003). Further, the idea of human rights seems to exclude the non-human entities (everything from animated trees and rocks to anthropomorphic spirit beings) that are part of Indigenous cosmology.

Peetush notes objections to these distinctions between western and indigenous thought by pointing out that Indigenous peoples themselves often use the discourse of human rights (Ibid.,: 197). But this may not be because they wish to travel the road to becoming westernized and liberal, but, rather, because they have no other possibility for bringing their problems forward.

\section{Awareness of the Tribunal}

Following my participation as an anthropological expert in the BC HR Tribunal in the Radek case, which I describe below, I received emails and phone calls from several Indigenous women, specifically hoping that they could follow in the footsteps of Gladys Radek and receive a favorable judgment in the tribunal. They believed that I could facilitate this. They were unclear about the process and I explained the grounds on which a suit could be brought to the tribunal and noted that they needed, at this point, legal rather than anthropological advice in putting together a case-including, potentially, finding witnesses, legal counsel, writing their brief to the court, and so forth.

None of these women who consulted me made it to the point where a ruling was rendered. My sense is that they found it frustrating and disappointing that the process is so technical and legalistic from the viewpoint of a layperson. They had hoped to tell their own stories of racial discrimination, harassment, and mistreatment. These communications to me suggested that some Aboriginal people are aware of the human rights idea but that how this works has not clearly filtered down to the public, including Aboriginal people. The Walkem report survey noted the lack of visibility of the tribunal for Indigenous peoples of BC (Walkem, 2019). Nevertheless, there is simultaneously a problem of volume-- the tribunal receives 100,000 hits per month on the website and 24,000 phone calls per year and tribunal personnel cannot give information on the complaint process over the telephone (personal communication, Bernd Walter, Tribunal Chair, February 17, 2015). British Columbia has now reinstituted a Human Rights Commission, which has among its duties, public education about the tribunal.

\section{Difficulties in the Process for Potential Complainants}

\section{Responses of Lawyers}

Lawyers who have worked in the tribunal as members or who represent clients note several distinct issues from their own perspective. Here I summarize their comments. Evidence, one lawyer noted, that might be transmitted orally, is lost in the process of writing out the case. This is an important moment in the transformation of a case from the issues troubling an Indigenous person into the legal categories acceptable 
to the tribunal but no longer recognizable by the litigant. Anthropologists Ewick and Silbey (1998) describe this significant process of cases moving through multiple lenses in the various phases of framing the case for trial, finally becoming transformed beyond meaning to the complainant.

Further, a lawyer observed that there are oddities of powers of the tribunal members which are assigned by statute and are less than the broader powers of ordinary courts. The members are limited in their ability to control disrespectful counsel and to maintain order in the courtroom. Examples are of counsel refusing to sit at the table and of horrible allegations made about clients. All of this has the effect of intimidating those who bring suit and are heard by the tribunal. In my own experience in the Radek case, Gladys Radek suffered through weeks of demeaning commentary from lawyers for the respondents, which affected both her and her child. Another, however, pointed out that while the Tribunal doesn't have contempt power it does have "costs power" which can be applied in instances such as lying under oath, improper accusations, and abusive language.

One lawyer points to even bigger, but less obvious issues. For First Nations people, he observes, it is hard to talk about discrimination, and that few topics are so personal and linked to the core of one's identity. Racial oppression, he notes, affects one's being but in the tribunal process is only has to be $a$ factor, not the only factor. A very significant issue is how to turn experiences of racial discrimination into evidence. Those people who prepared their own application to the tribunal struggle with their emotions and often make emotionally driven applications which are easy to undermine by the respondent's lawyers. This lawyer noted that giving testimony or the fear of giving testimony can trigger a post-traumatic stress syndrome, an issue which almost led one complainant in a case in which I served as expert to drop her case. As I noted regarding Radek, the whole process is aimed at undermining the credibility of an Indigenous person or persons who has brought an action. This is an issue I take up in more detail below.

\section{The Prospect of Emancipatory Breakthroughs, BC}

Another way of viewing the data regarding the limited number of decisions rendered and the difficulties of the process is to place emphasis on the cases that brought significant, emancipatory breakthroughs in establishing legal rights of Indigenous people. The Radek decision is an example of a dramatic breakthrough, was heralded in the media, and has come to be referenced in Canadian senior courts beyond the human rights tribunals. Testimony in Radek was relied on by the BC Supreme Court in a 2015 ruling regarding how to understand discrimination in Pivot $v$ Downtown Ambassadors, and in which the BC Supreme Court chided the $\mathrm{BC}$ HRT for insensitivity regarding discrimination against Aboriginal peoples (a ruling, however, which was overturned in the BC Court of Appeals).

The Radek case was described succinctly by the Georgia Straight, a Vancouver journal:

"In 2005, Radek won a major victory before the B.C. Human Rights Tribunal. The decision came down four years after she and a friend were harassed by security guards at downtown Vancouver's International Village, also known as Tinseltown, in 2001. She also complained in the suit that this incident was part of the systematic discrimination against aboriginal and disabled people resulting from the practices and policies of the mall and the guards it employed. The tribunal awarded Radek $\$ 15,000$, at that time the highest-ever payment for damages in a case involving race and disability

Gladys Radek herself, I believe, based on my own days with her during the hearing, underwent a transformation in going through the process and has become a significant national Indigenous leader. The ways in which the human rights process transforms individual Indigenous people is an important issue not reflected in the numbers, nor referenced by Walkem in her report. In a November 29, 2010 CBC News Website Radek described her experience, "The first time I used my voice was proving systemic racism through a human 
rights tribunal in 2005. This case was based on witnessing abuse toward aboriginal, poor and disabled people at Tinseltown Mall in Vancouver. It took four years to win this precedent-setting case." Radek herself has created a significant profile in the Indigenous world since this case, in part because of the case but perhaps more so because of her central role in the national controversy over missing women. Radek was a central leader in the widely publicized march to draw attention to the issue and became one of ten $\mathrm{CBC}$ nominees for a national prize for a "Champion of Change." (see Milward, 2012; Chartrand, 2014).

Clara Menzies, the complainant in another case I describe below, was disturbed by the prospects of giving testimony, but when the occasion arose, did so with very considerable power. (I use a pseudonym for the name of the complainant and obscure the name of the case for reasons of maintaining privacy). She, I believe, found providing her critique of Canadian society, the police, and the nature of racism to be important. During the hearing she assertively interrupted the tribunal member several times, spoke forcefully, and directly to her own concerns. Hers was a dramatic display of what is sometimes called speaking truth to power. Her responses were so forceful, in fact, that I feared that the tribunal member would find her testimony disruptive and lacking credibility (note, I did not believe that she lacked credibility). The member found quite the opposite, in fact.

\section{Materiality, Emotion, Trauma}

In speaking of the tribunal process, I refer to more than the actual hearing days, and instead include the meetings with lawyers, gathering of evidence, lunch gatherings during the hearings, and a range of other extra-tribunal events and processes. I will foreground issues of the materiality of the process and the emotional in particular.

First, the material: June McCue, an Indigenous woman and former law professor at UBC brought a case in which she argued that she had met the standards for tenure at the university but in an Indigenous, oral manner (a traditional Indigenous mode of communication and disseminating knowledge). The University disagreed and dismissed her. She was able to have her case accepted and heard, and she acted as her own lawyer. The University, meanwhile, deployed a staff lawyer and a lawyer with an outside practice specialized in human rights cases. I recorded some 200 pages of notes while attending the three weeks of hearings. It's worth noting that June McCue brought up an issue of great significance, the relevance of oral scholarship, to universities in their relations with Indigenous faculty.

The hearings itself are held in a downtown Vancouver government building, with most of one floor devoted to the BCHRT. Visitors enter into a hallway with a single reception window. To the right are the several hearings rooms and rooms for lawyer and clients to meet. The hallway bends around a corner, creating a complicated maze of space. It is very clearly a different realm one has entered. The hearing room themselves are small, perhaps ten meters by seven, and have tables set into a rectangle. There is no seat placed higher as in a court room, nor a special door for the tribunal member to enter and depart the hearing as in a conventional courtroom. The tribunal members do not wear judicial robes nor do lawyers bow as they enter and exit. Instead, everyone sits around the tables, with the exception of the few (usually no) visitors. There are four or five chairs for them. The person giving testimony sits across from the tribunal member. Clearly, an effort has been made to relax some of the formalities of the Canadian legal system.

But there are other, more telling issues to the material environment. In McCue's case, she relied on four over-sized suitcases filled with documents she intended to rely on during the hearings. As I got to know her by talking with her during the breaks in the hearings and during the lunch periods, I began to help her haul these heavy suitcases in and out of the hearings room every day. In the mornings, the suitcases were transported a few blocks from a parking garage. In the late afternoon the process was reversed. In total, the suitcases may 
have weighed fifty kilograms, far too much for one small woman to manage. But most significantly, during the hearings, McCue had to search through suitcases and the many dozens of documents to find the ones she needed to carry out cross-examination or to respond during her own examination by the University legal team. These delays while finding documents clearly annoyed the tribunal member, who repeatedly expressed his frustration with the delays. In turn, McCue herself suffered quietly, her own agitation and discomfort clearly expressed on her face and later in comments she made over lunch. This contrasts with the University legal team which had documents organized, no doubt by staff, and ready to use and to submit to the tribunal member. In brief, the mere volume of documents and the difficulty of organizing them and transporting them constituted an obstacle which McCue struggled to overcome. These problems eroded the patience of the tribunal member and damaged the efficacy of her presentation of McCue's issues.

I point to a second issue in the McCue case, which is the problem of cross-examination. Although McCue had been a law professor and legal scholar, in common with many law professors, she was not a legal practitioner and this showed in her cross-examinations of the various University authorities who had a role in her denial of tenure and whom she had called as witnesses. In two pages of notes (pages 76-77), I recorded that McCue was interrupted three times in just a few minutes by the tribunal member hearing the case. Other pages reveal many other interruptions, and the significance of interruptions and the ability to interrupt and control turn-taking has been identified by Conley and O'Barr as gendered expressions of power (1998).

At one point the member, in a gruff tone, commenting on McCue's difficulty in forming a question for the witness interrupts to say "You're making it so long she can't remember the elements [of your question]." Several minutes later he says "You make it very difficult-tell her what you want to concentrate on. I get a bunch of stuff. Make it easier for me." On another occasion (page 66 of notes) the member interrupted to tell McCue, "You are allowed to ask leading questions!" referring to a detail of common law regarding examination of witnesses. Hearing this, the UBC male lawyer mimicked the tribunal member's comment, and animatedly pointed at McCue, "You can ask leading questions! We're trying to help." Arguably, opposing counsel was not trying to help but was undermining McCue's presence and legitimacy in the tribunal room. He was mocking her. Two minutes later the member interrupted McCue's train of thought again to say, "I am going to ask, it begs to be asked. So the question is do you remember discussing oral traditions as publications?" McCue, in my observation visibly distraught by the repeated interruptions, remained calm and controlled, and soldiered on, her line of questioning and effectiveness thoroughly undermined.

McCue struggled to get witnesses to answer her questions directly, forced to rephrase and restate her questions in engaging recalcitrant witnesses. One University authority in particular answered "I don't recall" (page 64 of notes) many times consecutively and ducked many other questions. The tribunal member never admonished her for breaking the fundamental rule that witnesses must answer questions asked, allowing this evasion to continue. These are just a few examples of the hearing process. These circumstances point to a simple conclusion that without legal representation, Indigenous people have a slim chance of properly presenting their own case in the BCHRT.

Now to the emotive, concerning the Menzies case in which I gave expert testimony. In this instance, a tiny, middle-aged Indigenous woman while walking her dogs on the city streets one evening, happened upon her teen-age son while he was being arrested. She attempted to talk to him and give him a cigarette to see how he was and calm him down. But police blocked her view and carried her some forty feet from the scene and throwing her down. After being contracted to provide a report on systemic racism and related issues for the hearing I spoke privately with Ms. Menzies for three and a half hours in a women's advocacy center office. Although I had available to me the police reports I wanted to know from her what had happened in her own words. She expressed, in very forceful terms, her views of colonialism and the devastation Indigenous peoples have suffered and continue to suffer in addition to details of her own case. 
Later, the lawyer acting for the city police demanded my notes under the Common Law legal principal of discovery because I had referenced my conversation with Ms. Menzies in my report to the tribunal. She then told the lawyer, and later to me, that she intended to withdraw her case out of her fear of the police. She did not want, she said, the police to know anything more about her. In the end, the pro bono lawyer acting for her worked out an arrangement whereby I would withdraw portions of my report and not provide an opinion on the incident itself. Instead, only my theoretical section of my report on stereotyping, discrimination and policing and its effects on Indigenous people was allowed to be submitted.

This process of "thinning" the work of experts is repeated in the cases in which I have participated, and council for the respondents attempt to disqualify experts from areas of testimony. In the Radek case, opposing counsel attempted to argue that I could not use simple demographic tables in characterizing the neighborhood where Radek was arrested. The debate is fought out by opposing lawyers in voir dire hearings before the hearing itself, and the discussions about my qualifications do not allow my own participation. This is frustrating, because claims are made, I am told, about qualifications I lack. I have, in fact, studied as a graduate student and used demographic data as a professional.

The issue here is that the very cause of Clara Menzies bringing the case, namely her and other Indigenous peoples' relations with the police, became the reason she almost abandoned the case. And, it limited the sort of evidence which could be brought for her. This fear of authorities, particularly police, is a constant among Indigenous peoples as evident in this case, and as I have found in the others. Walkem notes this problem in her report, but the example I give here is how it manifests in an actual case. Fear is a profound barrier for Indigenous people's uses of the human rights mechanisms. This is so even for a brave and articulate woman like Clara Menzies

In both instances, McCue and Menzies, fear and other emotive states play a role and one might, as Walkem points out, describe the Indigenous participation in the tribunal as marked by trauma. I observed Gladys Radek, too experiencing the trauma of the process, although her reaction was different. She experienced days on end of commentary from the opposing lawyers who attempted to depict her in a negative light. Radek's daughter, in attendance at the hearings, was visibly distraught. One might rightfully ask if a traumatic process best serves Indigenous peoples whose experiences in the colonial process has been profoundly disruptive and traumatic.

\section{Discussion and Conclusions}

There are a number of statistical issues that can be brought to bear. The data from the cases of 19972015 (Miller research notes) show that the BC HRT attracts the interest of more potential and actual female complainants than male. Many more cases end up in mediation, with its own problems of power differentials, than in the tribunal itself. The tribunal is used against Indigenous institutions in cases brought both by Indigenous and non-Indigenous people. And, the difficulties people who have faced racism experience in creating an acceptable statement of complaint creates the grounds for dismissal. For these and many more reasons, the tribunal process is tremendously difficult for Indigenous people to navigate. Further, the evidence shows that many do not realize that a human rights tribunal might potentially be available to them.

In brief, the experiences of the lawyers acting for the complainants, those who have served as members of the BC HRT itself, and related evidence gathered concerning Indigenous awareness of the human rights practice itself, suggest that the human rights tribunal does not adequately serve the needs of Indigenous people, however "needs" might be defined. The evidence from BC tribunal cases appears to support this. Even though there are few cases which reach the finish line, each case adds to the body of precedent. Cases such as Radek have transformative power, both in the life of Gladys Radek herself, and in Canadian law in the human 
rights sector and beyond. These decisions in the HRT have carried over into senior provincial and federal courts regarding how discrimination might be understood and demonstrated. The facts I have presented here do not persuade me that the human rights tribunals must be viewed simply as eroding the possibilities for Indigenous peoples or as merely absorbing the energy of Indigenous peoples and deflecting criticisms of the state. There is more at play.

But in this paper, I point to the human experience of attempting to file and carry through with a case. The trauma of the process, even in the case of victory, as for both Radek and Menzies, is severe. McCue, too, suffered through the process. These Indigenous women experienced trauma during the process of being cross-examined, of sitting in the tribunal space, from derogatory and snide commentary, and of the foreignness of the process even for a law professor. As I point out, the process was materially onerous, resulting from carrying luggage, managing documents, managing witnesses, and, significantly, the costs of conducting a case. These costs including hiring experts, preparing documents, lost employment income, and more.

But perhaps the most significant feature was the fear experienced by the complainants bringing a suit, especially fear of police. All three of the Indigenous women mentioned here can only be described as brave, willing to submit themselves to the punishing experience, but many other unknown people would not be willing to submit. I found only 137 decisions in Indigenous cases in the seventeen years of decisions in the Tribunal that I reviewed. The fear the process generates is perhaps the greatest weakness of the BC HRT in its capacity to serve Indigenous people.

Received: January 28, 2021

Approved: August 30, 2021

\section{Bibliography}

BOXBERGER, Daniel T. 2004. "Whither the Expert Witness: Anthropology in the Post-Delgamuukw Courtroom”. In: Marie Mauzé, Michael Harkin, and Sergei Kan (eds.), Coming to Shore: Northwest Coast Ethnology, Traditions, and Visions. Lincoln: University of Nebraska Press. pp. 323-28.

CULHANE, Dara. 1998. The Pleasure of the Crown: Anthropology, Law, and First Nations. Vancouver: Talonbooks. CHRISTIE, Gordon. 2003. "Law, Theory and Aboriginal Peoples." Indigenous Law Journal, 2: 67-115.

CHARTRAND, Vicki. 2014. "Tears 4 Justice and the Missing and Murdered Women and Children Across Canada: An Interview of Gladys Radek." Radical Criminology: An Insurgent Journal, 3. Available at: wttp:/| www.journal.radicalcriminology.org/index.php/rc/article/view/25/html. Accessed May 2, 2016.

CONLEY, John M.; O’BARR, William M. 1998. Just Words: Law, Language and Power. Chicago: University of Chicago Press.

DARIEN-SMITH, Eve 2007. Ethnography and Law. New York: Routledge.

ELTRINGHAM, Nigel. 2012. "Spectators to the Spectacle of Law: The Formation of a 'Validating Public' at the International Criminal Tribunal for Rwanda”. Ethnos, 77(3): 425-445.

EWICK, Patricia; SILBEY, Susan S. 1998. The Common Place of Law: Stories from Everyday Life. Chicago:

University of Chicago Press. 
GOODALE, Mark. 2017. Anthropology and Law: A Critical Introduction. New York: NYU Press.

GREEN, Joyce (ed). 2014. Indivisible: Indigenous Human Rights. Halifax and Winnipeg: Fernwood Publishing.

MAWANI, Renisa. 2009. Colonial Proximities, Crossracial Encounters and Juridical Truths in British Columbia, 1871-1921.Vancouver: UBC Press.

MILLER, Bruce Granville. n.d. "Fieldnotes, Radek, McCue, Menzies. Notes; analysis of cases 1997-2015”. Mimeo.

MILWARD, David. 2012. Aboriginal Justice and the Charter: Realizing a Culturally Sensitive Interpretation of Legal Rights. Vancouver: UBC Press.

MULLINGS, Delores V. 2009. The Paradox of Exclusion within Equity: Interrogating Discourse at the Canadian Human Rights Tribunal. PhD dissertation, Lyle S. Hallman Faculty of Social Work, Wilfrid Laurier University.

NATIVE WOMEN'S ASSOCIATION OF CANADA. 2011. "The Canadian Human Rights Act and Aboriginal Women. Executive Summary Report and Focus Groups Recommendations”. In: Canada, A Report to Parliament On The Readiness of First Nations Communities And Organizations To Comply With The Canadian Human Rights Act. Minister of the Department of Indian Affairs and Northern Development. pp. 61-82.

PEETUSH, Ashwani K. 2009. "Indigenizing Human Rights: First Nations, Self-Determination, and Cultural Identity.” In: Priti Singh (ed.), Indigenous Identity and Activitism. Delhi: Shipra Publications.

STARR, June; GOODALE, Mark. 2002. Practicing Ethnography in Law: New Dialogues, Enduring Methods. New York: Palgrave-McMillan.

WALKEM, Edith. 2019. Expanding Our Vision: Cultural Equality \& Indigenous Peoples' Human Rights. Available at: http://www.bchrt.bc.ca/indigenous/index.htm, accessed April 16, 2020.

WILSON, Richard Ashby. 2006. "Afterword to 'Anthropology and Human Rights in a New Key': The Social Life of Human Rights.” American Anthropologist, 108(1): 77-83.

\section{Cases}

Menzies v. Vancouver Police Board (No. 2), 2019 BCHRT (number withheld).

Pivot Legal Society v. Downtown Vancouver Business Improvement Association and another (No. 6), 2012 BCHRT 23. Radek v. Henderson Development and other (No. 3), 2005 BCHRT 302.

Sharma, Madame Justice 2015 Reasons for Judgment, Vancouver Area Drug Users v. British Columbia Human Rights Tribunal. 2015 BCSC 534.

Bruce Granville Miller

Professor, University of British Columbia

Department of Anthropology

https://orcid.org/000o-0003-4951-1664

Email: bruce.miller@ubc.ca 